\title{
A New Optimum Frequency Controller of Hybrid Pumping System: Bond Graph Modeling-Simulation and Practice with ARDUINO Board
}

\author{
MEZGHANI Dhafer \\ Dept. of Physics, \\ Tunis El Manar University, Faculty \\ of Sciences, \\ Tunisia
}

\author{
MAMI Abdelkader \\ Dept. of Physics, \\ Tunis El Manar University, Faculty of Sciences, \\ Tunisia
}

\author{
OTHMANI Hichem \\ Dept. of Physics, \\ Tunis El Manar University, Faculty \\ of Sciences, \\ Tunisia
}

\author{
SASSI Fares \\ Dept. of Physics, \\ Tunis El Manar University, Faculty \\ of Sciences, \\ Tunisia
}

\author{
DAUPHIN-TANGUY Geneviève \\ Ecole Centrale de Lille, L.A.G.I.S. UMR CNRS 8146, BP \\ 48, 59651 Villeneuve d'Ascq, Cedex \\ France
}

\begin{abstract}
The strategy of rural development in Tunisia needs to include as one of its priorities: the control of water. In seeking solutions for the energy control dedicated to pumping, it seems interesting to know the benefits of a new technique based on the complementarities of two renewable energy sources such as solar and wind power. The climate's dependence requires a complex modelling and more optimization methods for controlling of hybrid system. Moreover, in recent years, technological progression at hardware and software enables researchers to process these optimization problems using embedded platforms. For this paper, we apply the approach bond graph to model a complex system. Our hybrid pumping installation contains a photovoltaic generator, a wind source, converters and an induction motor-pump group. The numerical closed-loop simulation of the complete model in an appropriate environment allows us to generate an optimisation control whose the appropriate frequency depends on meteorological conditions (wind speed, insulation and temperature). The implementation of this control and the experimental measurements validate the optimum efficiency and verify operation reliability of our hybrid structure.
\end{abstract}

Keywords-Hybrid power systems; Control systems; Optimization; Photovoltaic; wind turbine

\section{INTRODUCTION}

The decentralized electricity production by renewable energy sources, provides greater consumer supply security while respecting the environment. However, the random nature of these sources requires us to establish design rules and use these systems to exploit them. The majority of work is focused on the application of hybrid systems for the electrification of isolated consumers. Indeed, [1] presents a sizing strategy, based on a long-term energy production cost analysis, able to predict the optimum configuration of a hybrid PV-wind-diesel stand-alone system, which was tested on an isolated mountain chalet in Italy. As is the case of [2], the authors present modeling and optimization of a photovoltaic/wind/diesel system with batteries storage for electrification to an off-grid remote area located in Iran. For this location, different hybrid systems are studied and compared in terms of cost. For cost analysis, a mathematical model is introduced for each system's component and then, in order to satisfy the load demand in the most cost-effective way, particle swarm optimization algorithm are developed to optimally size the systems components. In addition, to decrease the cost and to increase the production of a hybrid system, [3] use a statistic distributions for estimation of the energy production of stand-alone hybrid wind turbinephotovoltaic system in southern Tunisia, So, the use of renewable energy (hybrid system: wind and photovoltaic) in these regions would be of great benefit, especially in remote locations. Hybrid systems can increase electrical energy for private consumers and small business and/or can be used to supply many applications as water pumping [4]. The complexity of the dynamic description of pumping stations and the many parameters involved in these systems have forced researchers to develop models based on different approaches. These approaches can be experimental, analytical or graphical approaches [5, 6]. All these approaches are intended to facilitate the task of managing these systems. In fact, the modeling and simulation are crucial in the design and analysis of hybrid systems. In the analysis and design of engineering problems, the most important thing is to perfectly know the process of technology. The success of the use of computer based tools to assist in the design, control, monitoring and modeling of these systems is critically dependent on the ability to develop accurate models for simulating, and verifying system behavior. Moreover, it is well known that the quality of the designed control method directly depends on the model accuracy. In literature, several methods for obtaining model could be found, among these methods, we quote the bond graph approach. This graphical methodology is a modeling approach where component energy ports are connected by bonds which specify the transfer of energy between system components [7]. In another words, the bond graph presents a 
method for obtaining dynamical models of different engineering systems [8-13]. The graphical methodology permits the decomposition of the system into subsystems exchanging energy, and to represent several physic domains (electricity, mechanical, hydraulic, etc.) with a unified way. In this paper, we present in the first part, the bond graph models of the elements constituting our pumping hybrid installation. Then, we work out an improved control, which has been established from the simulations for several weather conditions. Finally, measurements were carried out on the experimental device that enabled us to validate the adopted control and to check the operation reliability of studied structure.

\section{MODELling BY BOND GRAPH OF PUMPING HYBRID INSTALLATION}

The bond graph tool (or link graph) is as an intermediary between the physical system and the mathematical models associated with it. It provides a unified modeling tool applicable to all domains of physics (electrical, mechanical, hydraulic...). This will facilitate the study of composed systems. Bond graph modeling has been used in applications of analysis, simulation, calculation of control and monitoring. It has given very interesting search results. Table 1 concludes the advantages of bond graph by application [14-20].

TABLE I. BOND GRAPH AND APPLICATIONS

\begin{tabular}{|c|c|}
\hline Application & advantages \\
\hline Modeling & $\begin{array}{l}\text { - } \quad \text { Makes possible the energetic study } \\
\text { Makes simpler the building of models for } \\
\text { multi-disciplinary systems } \\
\text { Leads to a systematic writing of } \\
\text { mathematical models (linear or nonlinear } \\
\text { associated }\end{array}$ \\
\hline Analysis & $\begin{array}{l}\text { Estimation of the dynamic of the model and } \\
\text { identification of the slow and fast variables } \\
\text { - } \quad \text { Study of structural properties }\end{array}$ \\
\hline Control & 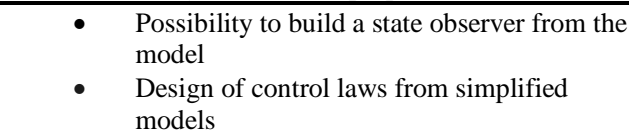 \\
\hline Identification & $\begin{array}{ll}-\quad & \text { No "black box" model } \\
\text { - } & \text { Identification of unknown parameters, but } \\
\text { knowledge of the associated physical } \\
\text { phenomena }\end{array}$ \\
\hline Monitoring & $\begin{array}{l}\text { - Graphical determination of the } \\
\text { "monitorability" conditions and of the } \\
\text { number and location of sensors to make the } \\
\text { faults localizable and detectable }\end{array}$ \\
\hline Simulation & $\begin{array}{l}\text { - } \\
\text { Specific software (CAMP+ASCL, } \\
\text { ARCHER, } 20 \text { SIM) } \\
\text { A knowledge of the numerical problems } \\
\text { which may happen (algebraic-differential } \\
\text { equation, implicit equation) by the means of } \\
\text { causality }\end{array}$ \\
\hline
\end{tabular}

The generalized power variables by bond graph modeling are the effort 'e' and the flow ' $f$ ' whose product expresses the power transmitted by the bond. Also, it defines the power generalized variables: the momentum $\left(p=\int e d t\right)$ and the displacement $\left(q=\int f d t\right)$. These two variables are state variables. Knowledge of these variables allows us to know the dynamic state of the whole system considered [21-25]. Besides the description of the system, each of the four variables has a physical meaning regardless of the field. Table 2 shows which physical quantities are commonly chosen as effort and flow variables in the different energy domains.

TABLE II. BOND GRAPH VARIABLES USED IN THE VARIOUS ENERGY DOMAINS

\begin{tabular}{|c|c|c|c|c|}
\hline $\begin{array}{l}\text { Energy } \\
\text { domain }\end{array}$ & Effort e & Flow $f$ & $\begin{array}{l}\text { Generalized } \\
\text { momentum } \\
\text { p }\end{array}$ & $\begin{array}{l}\text { Generalized } \\
\text { displacement } \\
\text { q }\end{array}$ \\
\hline $\begin{array}{l}\text { Rotational } \\
\text { mechanics }\end{array}$ & $\begin{array}{l}\text { Angular } \\
\text { Moment } \\
\text { C (N.m) }\end{array}$ & $\begin{array}{l}\text { Angular } \\
\text { velocity } \\
\Omega(\mathrm{rd} / \mathrm{s})\end{array}$ & $\begin{array}{l}\text { Angular } \\
\text { momentum } \\
\mathrm{P}(\mathrm{Nms})\end{array}$ & $\begin{array}{l}\text { Angular } \\
\theta(\mathrm{rd})\end{array}$ \\
\hline Electro- & $\begin{array}{l}\text { Voltage } \\
\mathrm{U}(\mathrm{V})\end{array}$ & $\begin{array}{l}\text { Current } \\
\text { I (A) }\end{array}$ & $\begin{array}{l}\text { Linkage flux } \\
\lambda(\mathrm{Vs})\end{array}$ & $\begin{array}{l}\text { Charge } \\
\mathrm{Q}(\mathrm{C})\end{array}$ \\
\hline $\begin{array}{l}\text { Magnetic } \\
\text { domain }\end{array}$ & $\begin{array}{l}\text { Magnetomoti } \\
\text { ve force V } \\
\text { (A) }\end{array}$ & $\begin{array}{l}\text { Magnetic } \\
\text { flow rate } \\
\dot{\emptyset}(\mathrm{Wb} / \mathrm{s}) \\
\end{array}$ & - & $\begin{array}{l}\text { Magnetic } \\
\text { flow } \\
\phi(\mathrm{Wb})\end{array}$ \\
\hline hydraulic & $\begin{array}{l}\text { Total pressure } \\
\mathrm{P}\left(\mathrm{N} / \mathrm{m}^{2}\right)\end{array}$ & $\begin{array}{l}\text { Volume } \\
\text { flow } \\
\text { Q }\left(\mathrm{m}^{3} / \mathrm{s}\right. \\
\end{array}$ & $\begin{array}{l}\text { Pressure } \\
\text { momentum } \\
\mathrm{Pp}\left(\mathrm{N} / \mathrm{m}^{2} \mathrm{~s}\right)\end{array}$ & $\begin{array}{l}\text { Volume } \\
\text { Ve }\left(\mathrm{m}^{3}\right)\end{array}$ \\
\hline $\begin{array}{l}\text { Thermodyn } \\
\text { amic }\end{array}$ & $\begin{array}{l}\text { Temperature } \\
\mathrm{T} \\
(\mathrm{K})\end{array}$ & $\begin{array}{l}\text { Entropy } \\
\text { flow } \\
\dot{S}(\mathrm{~J} / \mathrm{K})\end{array}$ & - & $\begin{array}{l}\text { Entropy } \\
\text { S (J/K) }\end{array}$ \\
\hline
\end{tabular}

The bond graph elements can be classified as follows:

- $\quad$ simple passive elements : R, C and I

- Active elements : sources Se, Sf , and MSe MSf

- Junction elements : 0, 1, TF, GY, MTF and MGY

The assignment rules of the elements and the junctions are described in the table 3 .

TABLE III. BOND GRAPH AFFECTATION

\begin{tabular}{|c|c|}
\hline Element & Causality and equation \\
\hline $\mathrm{R}$ & $\begin{array}{ll}R \Longleftarrow & e=R . f \\
R \longmapsto & f=e / R\end{array}$ \\
\hline C dynamic & $\mathrm{C}<-1$ \\
\hline L dynamic & $\mathrm{Ir}$ \\
\hline $\begin{array}{l}\text { Same } \\
\text { domai } \\
\mathrm{n}\end{array}$ & 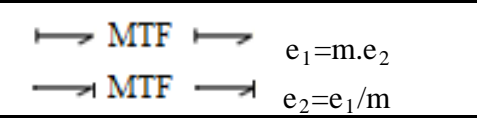 \\
\hline $\begin{array}{c}\text { Different } \\
\text { domai } \\
n\end{array}$ & $\begin{array}{l}\longrightarrow \mathrm{MGY} \longmapsto \mathrm{f}_{1}=\mathrm{e}_{2} / \mathrm{r} ; \mathrm{f}_{2}=\mathrm{e}_{1} / \mathrm{r} \\
\mathrm{e}_{1}=\mathrm{r.f}_{2} ; \mathrm{e}_{2}=\mathrm{r}_{1}\end{array}$ \\
\hline Junction 0 & $\stackrel{2 !}{2 !}$ \\
\hline Junction 1 & 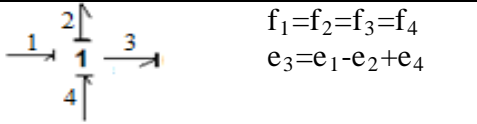 \\
\hline
\end{tabular}


For our hybrid system modelling, we used the bond graph tool which constitutes an intermediate between the physical system and its mathematical models (matrix of transfer, state equations, etc.).The often bond graph modelling has been used for systems simulation. The schematic block of hybrid pumping system is given by Figure 1 .

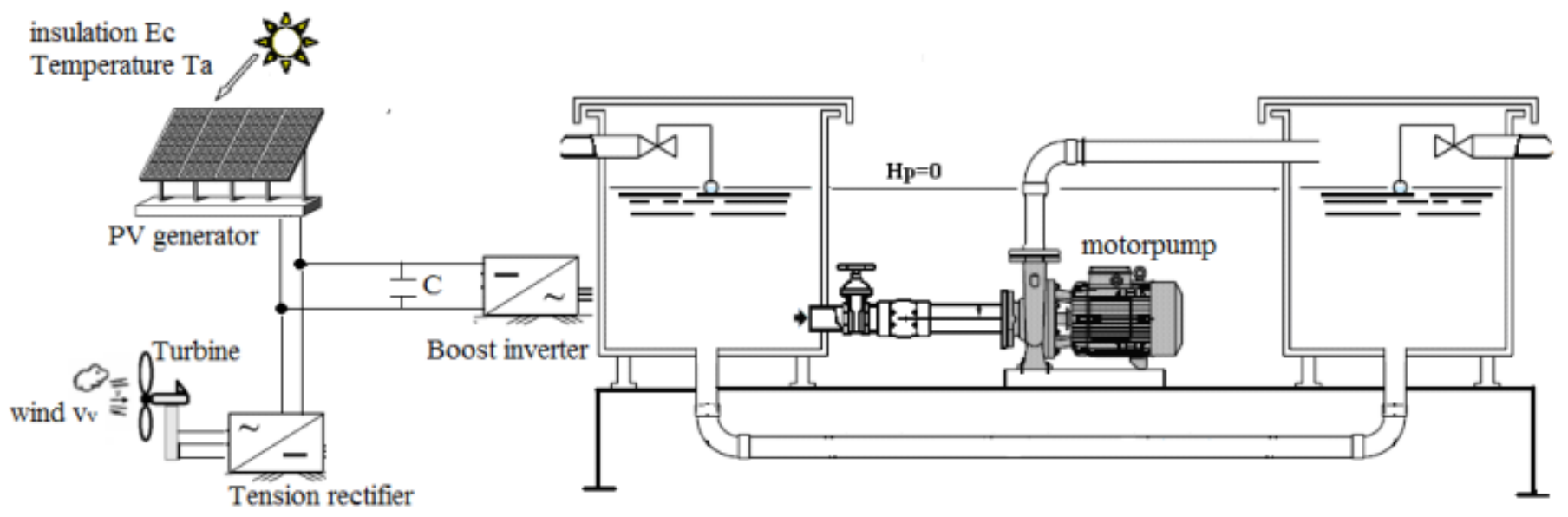

Fig. 1. Schematic block of PV pumping system

The conversion of climatic conditions (irradiance $E_{c}$, ambient temperature Ta and Junction Temperature $T_{p}$ ) into electricity by the photovoltaic process is a mean of solar exploitation. The PV generator a special energy source, it's characterized by a nonlinear current-voltage curve. The PV generator behavior is equivalent to a current source shunted by a junction diode. By neglecting photovoltaic cell physical phenomena such as contact resistances and the current lost by photocell sides as well as the aging of cells. The bond graph model of the equivalent PV panel coupled to a starting up capacitance is given by the Figure $2-\mathrm{a}$ and Figure 2 - b with $\mathrm{RD}$ is the nonlinear PV diode resistance [26].

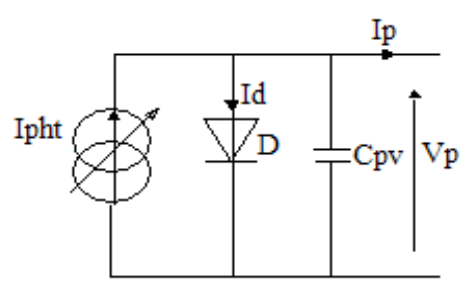

(a)

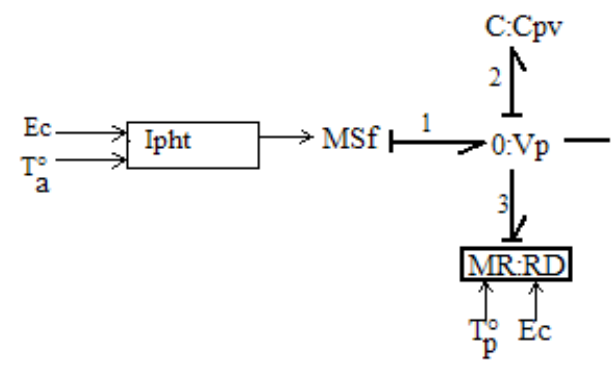

(b)

Fig. 2. (a) Schematic block of PV pumping system (b) Reduced bond graph model of the PV source

The I-V solar generator characteristic $[27,28]$ is represented by the Eqs. (1), (2) and (3).

$$
I_{p}=I_{p h t}-I_{s S t} .\left(\exp \left(\frac{q \cdot V_{p}}{n_{i} \cdot K \cdot T_{a}}\right)-1\right)
$$

With

$$
I_{p h t}=\left(I_{c c}\left(\frac{E_{c}}{E_{0}}\right)+j \frac{E_{c}\left(T_{a}-T_{0}\right)}{E_{0}}\right)
$$

And

$$
\mathrm{I}_{\mathrm{sst}}=\mathrm{I}_{\mathrm{s}} \mathrm{T}_{\mathrm{p}}^{3} \exp \left\{\frac{-\mathrm{Eg}_{\mathrm{g}}}{\mathrm{K} \cdot \mathrm{T}_{\mathrm{p}}}\right\}
$$

The wind turbine is constituted by blades and a permanent magnet synchronous machine [29], the bond graph model is given by the Figure 3.

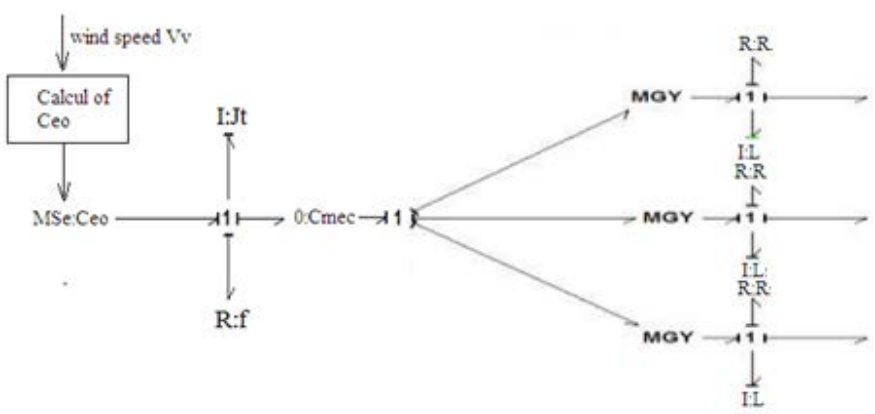

Fig. 3. Bond graph of the wind turbine

The calculation block of the wind torque $\mathrm{C}_{\mathrm{eo}}$ includes the Eq. (4).

$$
\mathrm{C}_{\mathrm{eo}}=\frac{\mathrm{C}_{\mathrm{p}}(\lambda) \cdot \rho \cdot \mathrm{R}_{\mathrm{w}}{ }^{2} \cdot \mathrm{H}_{\mathrm{w}} \cdot \mathrm{V}_{\mathrm{v}}^{2}}{\lambda}
$$


The tests performed on the wind turbine of laboratory allow to find the coefficient of power $\mathrm{C}_{\mathrm{p}}$ by a polynomial interpolation given by Eq. (5).

$$
\mathrm{C}_{\mathrm{p}}(\lambda)=\mathrm{c}_{3} \cdot \lambda^{3}+\mathrm{c}_{2} \cdot \lambda^{2}+\mathrm{c}_{1} \cdot \lambda+\mathrm{c}_{0}
$$

Where $\lambda$ represents the specific speed.

$$
\lambda=\frac{R_{w .} \Omega}{V_{v}}
$$

The rectifier ensure the generation of a constant voltage at its output (on DC bus (Vdc)) by an internal microprocessor in the wind generator, the electrical scheme of the DC bus is illustrate by Figure 4 - a. The bond graph model of this rectifier is given by Figure 4 - $b$.

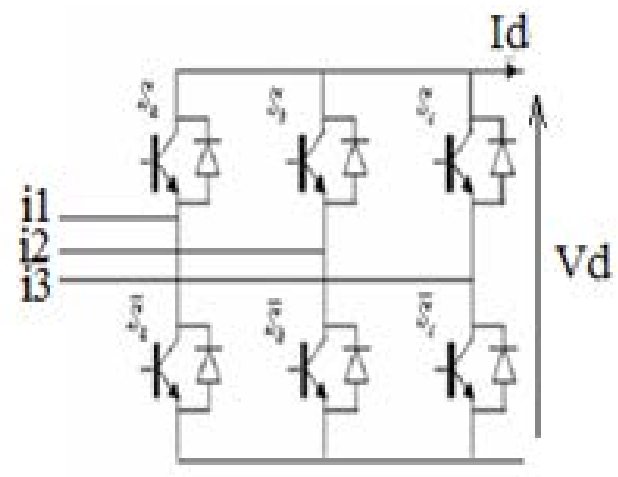

(a)

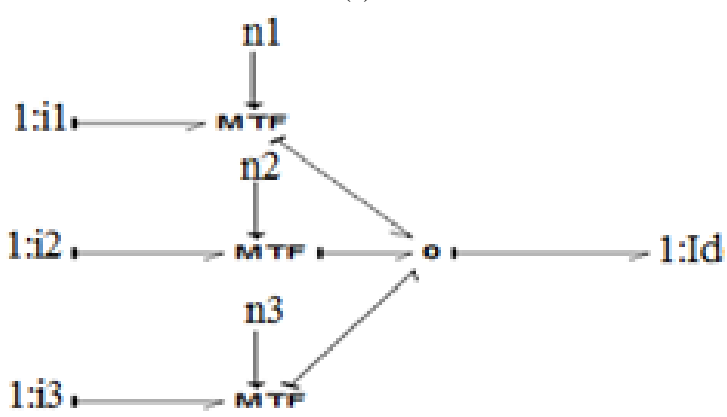

(b)

Fig. 4. (a) Schematic block of PV pumping system (b) Bond graph of the rectifier

The bus current Idc is given by the logic control presented by Eq. (7).

$\mathrm{Idc}=\eta_{1} \mathrm{i}_{1}+\eta_{2} \mathrm{i}_{2}+\eta_{3} \mathrm{i}_{3}=\left(\frac{1}{3}\left(2 \mathrm{~S}_{1}-\mathrm{S}_{2}-\mathrm{S}_{3}\right)\right) \mathrm{i}_{1}+\left(\frac{1}{3}\left(2 \mathrm{~S}_{2}-\mathrm{S}_{1}-\mathrm{S}_{3}\right)\right) \mathrm{i}_{2}+\left(\frac{1}{3}\left(2 \mathrm{~S}_{3}-\mathrm{S}_{1}-\mathrm{S}_{2}\right)\right) \mathrm{i}_{3}$

The wind generator delivers a constant voltage of $24 \mathrm{~V}$ order (Appendix) from the wind speed $(2.9 \mathrm{~m} / \mathrm{s})$, we associating a boost converter controlled by its ratio cyclic $\mathrm{D}$, its electrical diagram, its principle and the PWM control are widely discussed in the literature [30 - 32], we present the BG model, coupling to ensure sufficient voltage to the workings of our pumping system. The coupling of the two sources is done via a DC bus, as shown in Figure 5.

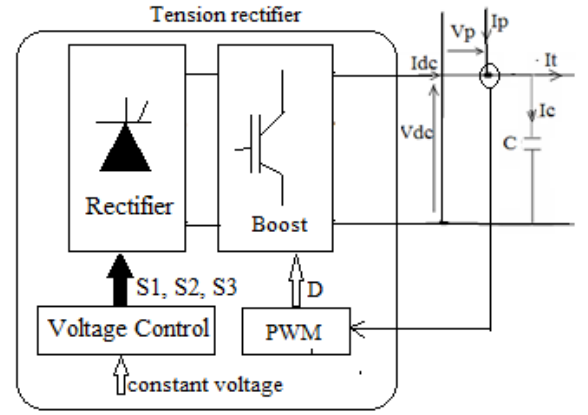

(a)

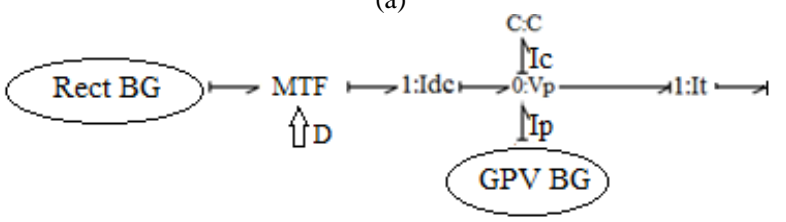

(b)

Fig. 5. (a) Electrical scheme of the DC (b) Bond graph of the DC bus

We consider the case where the inverter is ideal and its switches are perfect and switch instantly. This inverter is controlled by a Pulse Width Modulation strategy. The schematic diagram is shown in Figure 6 - a. The bond graph model of the Figure $6-\mathrm{b}$ is inferred from the relationship describing the operation of the three arms of the boost inverter [33; 34].

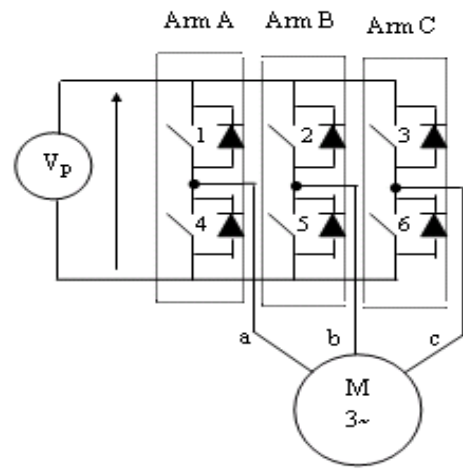

(a)

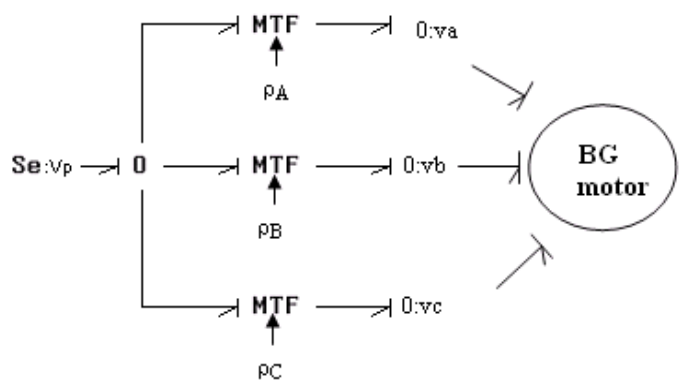

Fig. 6. (a) Schematic diagram of the tension (b) Averaged BG model associated

We indicate by $\rho$ i the cyclic ratio of each arm of inverter ( $\mathrm{i}=\mathrm{A}, \mathrm{B}, \mathrm{C})$, This inverter is coupled to an induction motorpump, his Thevenin electrical schemes is given along the axis $\mathrm{D}$, and deduced from the model of Park, it's represented by the 
Figure 7 - a and the Figure 7 - b, the BG model correspondent is given by the Figure 7 - c [34].

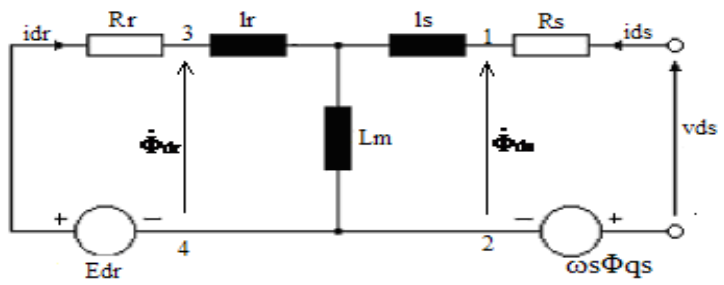

(a)

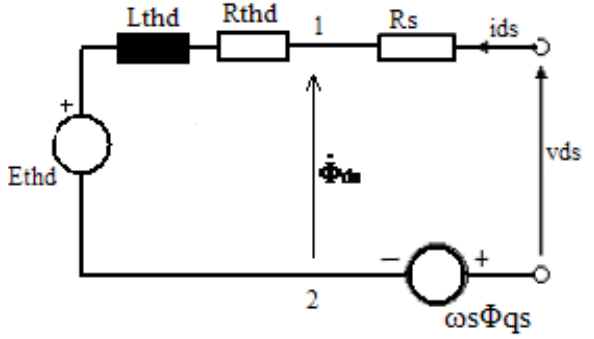

(b)

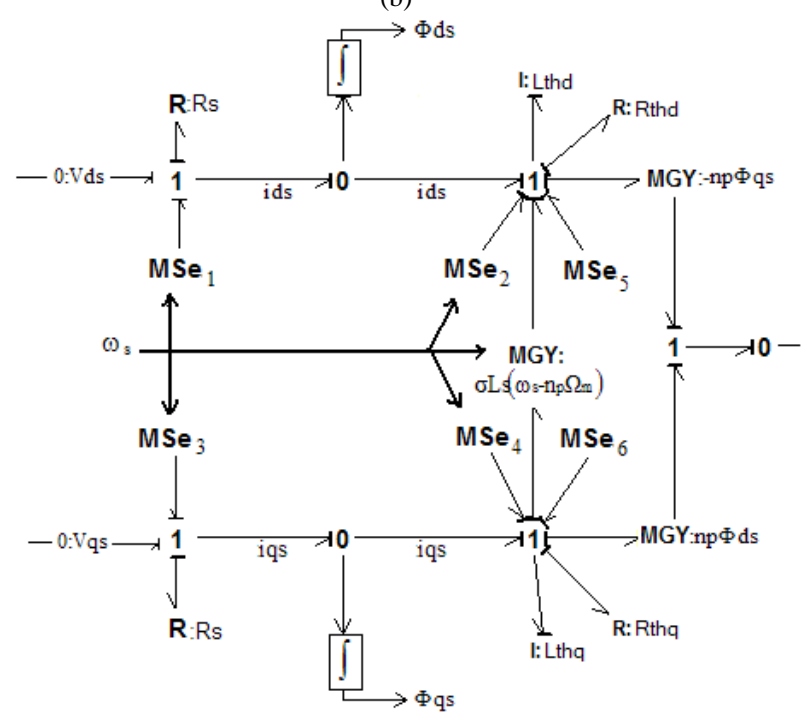

Fig. 7. (a) Park model of motor following axis d (b) Thevenin Model (c) Bond graph model

In the BG model in Figure 7-c, the elements MSe take the following values:

$\left(\mathrm{MSe}_{1}=\omega_{\mathrm{s}} \Phi_{\mathrm{qs}}, \mathrm{MSe}_{2}=-\omega_{\mathrm{s}} \Phi_{\mathrm{ds}}, \mathrm{MSe}_{3}=-\omega_{\mathrm{s}} \Phi_{\mathrm{qs}}, \mathrm{MSe}_{4}=\omega_{\mathrm{s}}\right.$ $\left.\Phi_{\mathrm{ds}}, M S e_{5}=\frac{R_{r}}{L_{r}} \Phi_{d s}, M S e_{6}=\frac{R_{r}}{L_{r}} \Phi_{q s}\right)$.

For our application, the pump used is of centrifugal type, and the two tanks are communicating between them, the Eq. (8) characteristic of the hydraulic network binding the flow Q and the mechanical speed $\Omega \mathrm{m}$ is given by the first law of similarity.

$$
\Omega_{\mathrm{m}}=\left(\frac{2\left(\mathrm{~b}_{2}-\psi\right)}{-\mathrm{b}_{1}-\sqrt{\mathrm{b}_{1}^{2}-4 \mathrm{~b}_{0}^{2}\left(\mathrm{~b}_{2}-\psi\right)}}\right) \mathrm{Q}=\left(\frac{\Omega_{\mathrm{nom}}}{\mathrm{Qnom}_{\mathrm{m}}}\right) \mathrm{Q}
$$

In more, the motor-pump is characterized by its following aerodynamic Eq. (9).

$$
\mathrm{C} e \mathrm{~m}=\mathrm{C}_{2} \Omega_{\mathrm{m}}^{2}+\mathrm{C}_{1} \Omega_{\mathrm{m}}+\mathrm{J} \frac{\mathrm{d} \Omega_{\mathrm{m}}}{\mathrm{dt}}
$$

Thus, the BG model of hydraulic circuit is given by the Figure 8 .

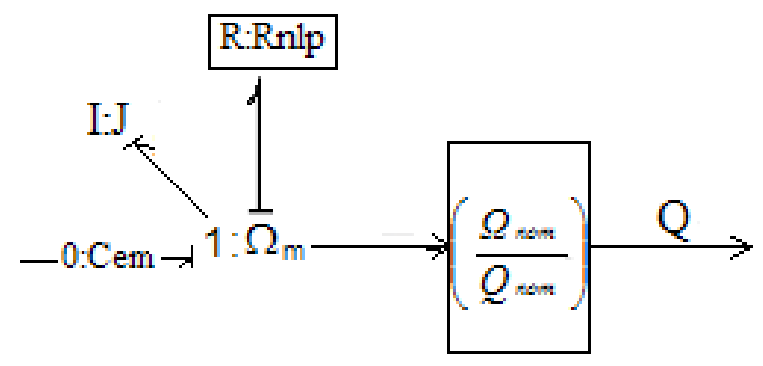

Fig. 8. BG model of centrifugal pump and hydraulic circuit

\section{THE OPTIMUM FREQUENCY CONTROLLER OF HYBRID SYSTEM}

The obtained model is then realized in 20-sim software environment [35], A closed-loop V/f control system, applied to an induction motor, is fed by a PWM three phase voltage inverter. For a wind speed (between 3.1 and $14.2 \mathrm{~m} / \mathrm{s}$ ), the hybrid system considered functions with the sun wire and since the weather conditions (EC and $\mathrm{Ta}$ ) are variable according to time. Then, it's necessary to adapt the operation point of load to the maximum power provided by the hybrid source through the frequency of the inverter which varies with the climatic conditions and it according to an optimum V/f control. Thus, it makes possible to ensure an optimum efficiency of the structure. The simulation scheme is given by the Figure 9 .

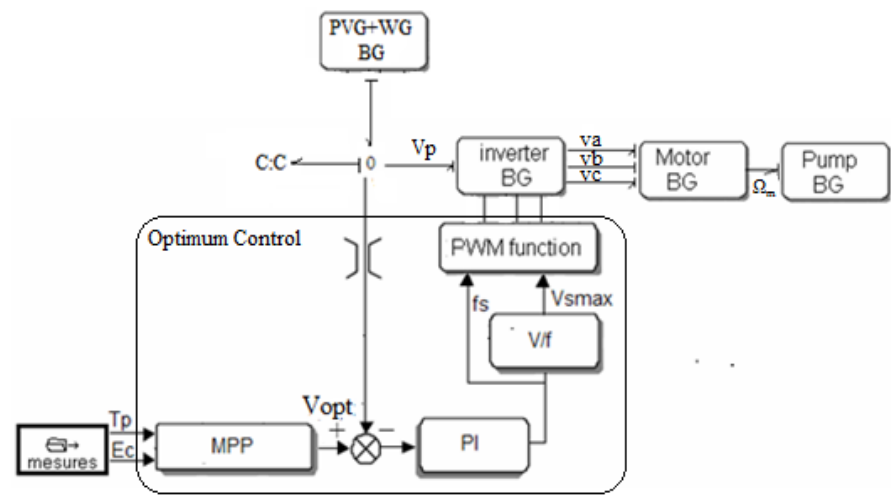

Fig. 9. The scheme of the pumping hybrid system in closed loop

Finally, The digital simulation of the structure in closed loop shows that the stator frequency $\mathrm{f}_{\mathrm{S}}$ varies in function the variables $E_{C}$ and $T_{a}$ as the Figure 10 shows it, a polynomial interpolation of high order enables us to define two frequencies $f_{\mathrm{SE}}$ and $f_{\mathrm{ST}}$ given by the eq. (5) and finally the value of stator frequency applied to the machine is calculated from the algorithm of the Figure 10. 


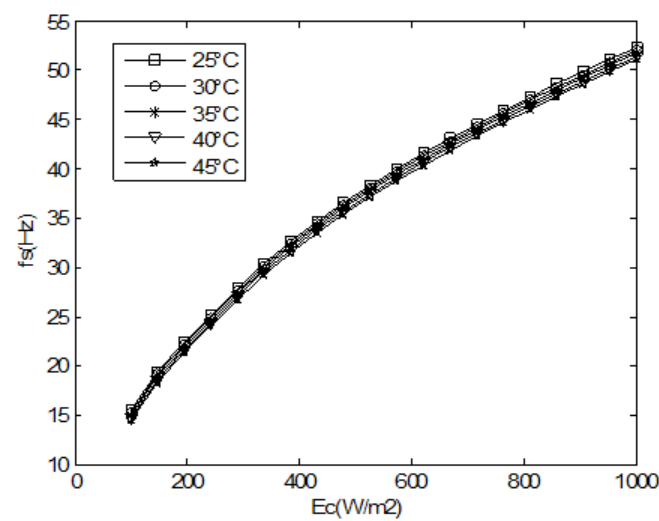

Fig. 10. Frequency depending of ambient temperature and insulation

The adopted MPPT method generates the stator frequency fs, it depends of the insulation Ec and the ambient temperature Ta as shown in Figure 10. It's given by the following Eq. (10).

$$
f_{s}=f 0+(\operatorname{sign}(\Delta E) \cdot \Delta f E) \cdot C E+(\operatorname{sign}(\Delta T) \cdot \Delta f T) \cdot C T
$$

In this equation, the variations $\Delta \mathrm{f}_{\mathrm{E}}$ and $\Delta \mathrm{f}_{\mathrm{T}}$ are given by the system Eq. (11).

$$
\left\{\begin{aligned}
\Delta f_{E} & =f_{s E_{0}}-f_{s E} & & \text { for } \Delta T=0 \\
\Delta f_{T} & =f_{s T_{0}}-f_{s T} & & \text { for } \Delta E=0
\end{aligned}\right.
$$

Where frequencies $f_{S E 0}$ et $f_{S E}$ (resp. $f_{s T 0}$ and $f_{S T}$ ) are respectively the frequencies to $E_{0}$ (resp. $T_{0}$ ) and $E_{c}$ (resp. $T_{a}$ ), are calculated by polynomial interpolation, they are given by the system of Eq. (12).

$$
\left\{\begin{array}{llc}
f_{s E}=310^{-13} E_{c}{ }^{5}-910^{-10} E_{c}{ }^{4}+10^{-6} E_{c}{ }^{3}+0.194 E_{c}+0.167 & ; & \text { for } T p=c t \\
f_{s T}=-10^{-4} T_{a}{ }^{2}-0.054 T_{a}+53.76 & ; & \text { for } E c=c t
\end{array}\right.
$$

In addition, the orders CE et CT are defined by the system Eq. (13).

$$
\left\{\begin{array}{rlrl}
C_{E}\left(\operatorname{resp} . C_{T}\right) & =1 & & \text { for } \Delta E(\operatorname{resp} . \Delta T)=0 \\
C_{E}\left(\operatorname{resp} . C_{T}\right)=0 & & \text { for } \Delta E(\operatorname{resp} . \Delta T)=0
\end{array}\right.
$$

Where

$$
\Delta E=E_{c}-E 0 \text { and } \Delta T=T p-T 0
$$

The measurements on our hybrid source shows that the junction temperature Tp depends of the wind speed and the insulation Ec by exponential interpolation according to the Eq.(13)

$$
\left\{\begin{aligned}
C_{E}\left(\operatorname{resp} . C_{T}\right) & =1 & & \text { for } \Delta E(\operatorname{resp} . \Delta T)=0 \\
C_{E}\left(\operatorname{resp} . C_{T}\right) & =0 & & \text { for } \Delta E(\operatorname{resp} . \Delta T)=0
\end{aligned}\right.
$$

At the STC $\left(25^{\circ} \mathrm{C}, 1000 \mathrm{~W} / \mathrm{m} 2\right)$, the corresponding reference frequency f0 $(49 \mathrm{~Hz})$.

\section{IMPLEMENTATION AND DISCUSSION}

In order to validate the bond graph model of the pumping hybrid system and to simulate the real behavior of hybrid system, it's necessary to have the experimental results measurement and acquisition of various sizes. The CPU of

\begin{tabular}{|c|c|}
\hline Electrical Data & Value \\
\hline Nominal output power (W) & 370 \\
\hline Nominal elect power(W) & 550 \\
\hline Max Flow Rate (l/min) & 35.6 \\
\hline Max head (m) & 7 \\
\hline Statoric resistor $(\Omega)$ & 24.6 \\
\hline Rotoric resistor $(\Omega)$ & 16.1 \\
\hline Mutual self(H) & 1.46 \\
\hline Rotoric self (H) & 1.48 \\
\hline Statoric self(H) & 1.49 \\
\hline \multicolumn{2}{|c|}{$\begin{array}{l}\text { Coeff of pump } \mathrm{C}_{1}=1.7510-3 \mathrm{~kg} \cdot \mathrm{m}^{-2} \cdot \mathrm{s}-1, \mathrm{C}_{2}=7 \cdot 510-6 \\
\mathrm{Kg} \cdot \mathrm{m}^{-4} \cdot \mathrm{s}^{-2}, \mathrm{~J}=6.510-3 \mathrm{Kg} \cdot \mathrm{m}^{-1}, \mathrm{~b}_{0}=4.5210^{-4} \\
\min ^{2} \cdot \mathrm{m} \cdot \mathrm{tr}^{-2}, \quad \mathrm{~b}_{1}=-1.96610^{-3} \mathrm{~m} \mathrm{~min} 2 \cdot \mathrm{tr}^{-1} \cdot \mathrm{L}^{-1}, \\
\mathrm{~b}_{2}=-0.012 \mathrm{~min}^{2} \cdot \mathrm{m} \cdot \mathrm{L}^{-2}, \Psi=4.081610^{-3} \\
\mathrm{~min}^{2} \cdot \mathrm{m} \cdot \mathrm{L}^{-2}\end{array}$} \\
\hline
\end{tabular}
microcontroller Arduino [36] uses the data to control the tension inverter by his frequency. In the Figure 11 - a, this inverter (element 1) fed a motor-pump EBARA (element 2), the electrical specifications of our induction machine is described by table 4 .

TABLE IV. SPECIFICATIONS OF EBARA

Our hydraulic system includes different sensors: pressure (element 7), flow (element 5) and level (element 6). The pipe (element 3) is connected by a valve assembly (element 4). For this installation, each PV panel is described by the table 5, so, we combine four PV panels in series delivering enough power for pumping, the turbine, associated to converters, is coupled to the DC bus with an internal regulation, it has sufficient voltage for low illumination, these renewable sources are given by the Figures 11 - b and the Figure 11 - c.

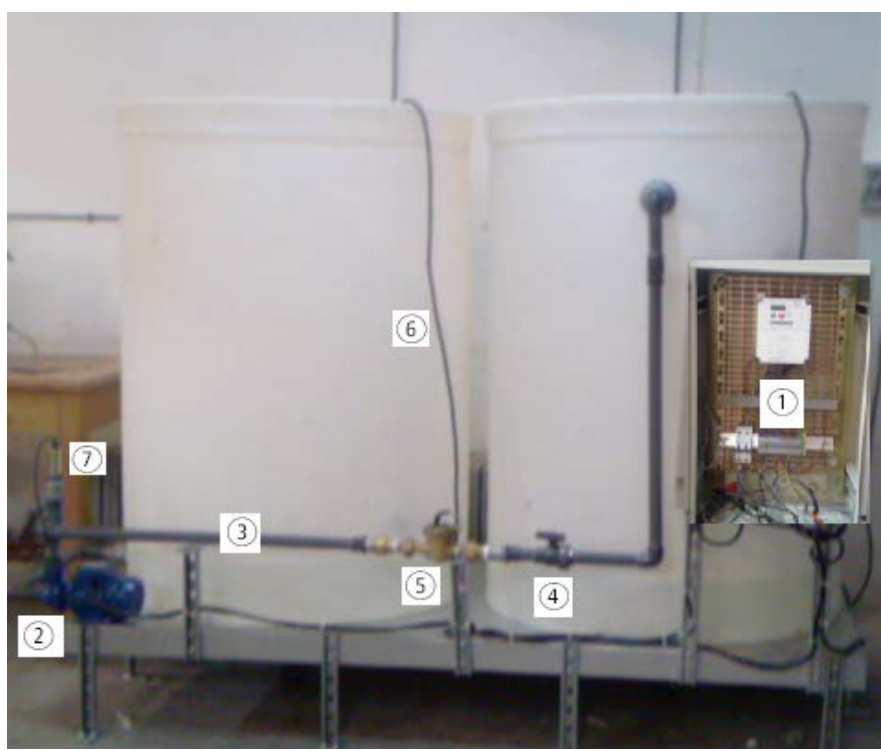

(a) 


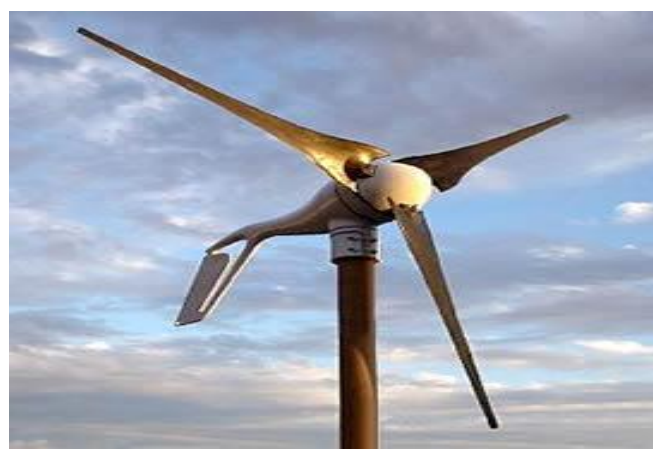

(b)

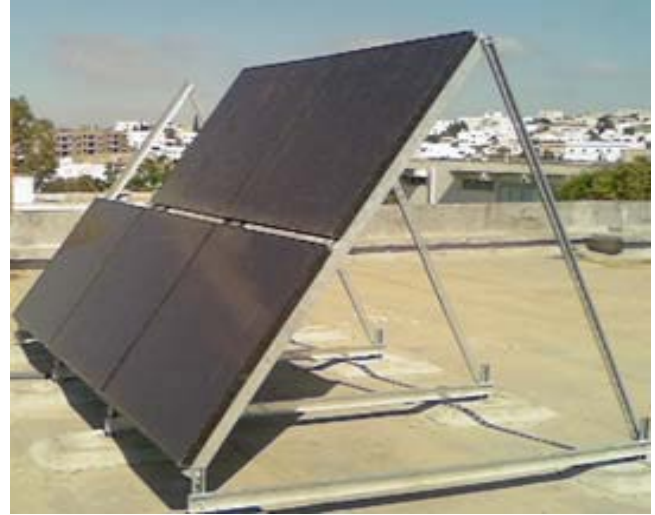

(c)

Fig. 11. (a) Hydraulic system (b) The wind turbine AIRX 400 (c) Photovoltaic field KANEKA

TABLE V. CHARACTERISTICS OF KANEKA 60

\begin{tabular}{|l|l|}
\hline Electrical Data & Value \\
\hline Nominal output Pmpp(W) & 60 \\
\hline Nominal Voltage Umpp & 67 \\
\hline Nominal current Impp(A) & 0.9 \\
\hline Open circuit voltage Uoc(V) & 92 \\
\hline Short circuit current Isc(A) & 1.19 \\
\hline Temp coeff of Isc $\left[\% /{ }^{\circ} \mathrm{C}\right]$ & 0.075 \\
\hline Temp coeff of Uoc $\left(\mathrm{mV} /{ }^{\circ} \mathrm{C}\right)$ & -280 \\
\hline Temp coeff Output $\left(\% /{ }^{\circ} \mathrm{C}\right)$ & -0.23 \\
\hline
\end{tabular}

TABLE VI. CHARACTERISTICS OF AIRX-400

\begin{tabular}{|l|l|}
\hline Specification & Value \\
\hline Start-up wind speed(m/s) & 3.13 \\
\hline Output voltage $(\mathrm{V})$ & 24 \\
\hline Rated Power(W) & 400 \\
\hline Turbine Controller: & $\mu \mathrm{P}$ \\
\hline Rated wind speed(m/s) & 12.5 \\
\hline Rotor Diameter $(\mathrm{m})$ & 1.15 \\
\hline \begin{tabular}{l} 
Coeff of Turbine \\
$\mathrm{C}_{3}=-210^{-4}, \mathrm{c}_{2}=-2.810^{-3}, \mathrm{c}_{1}=9.410^{-2}, \mathrm{c}_{0}=10^{-4}$ \\
\hline
\end{tabular}
\end{tabular}

From the measurements of the wind turbine and using its parameters given by table 6 , the electrical output power curve of our turbine, represented by the Figure 12, can develop energy from low speed $(9.64 \mathrm{Km} / \mathrm{h}$ or $2.6 \mathrm{~m} / \mathrm{s})$ as it can operate at high speeds up to $500 \mathrm{~W}$ at $50 \mathrm{Km} / \mathrm{h}$. At nominal speed wind $\left(\mathrm{V}_{\mathrm{v}}=12 \mathrm{~m} / \mathrm{s}\right)$ the electric power reaches a value of $400 \mathrm{~W}$ for optimal power coefficient $\quad \mathrm{C}_{\mathrm{p}}=0.49$.

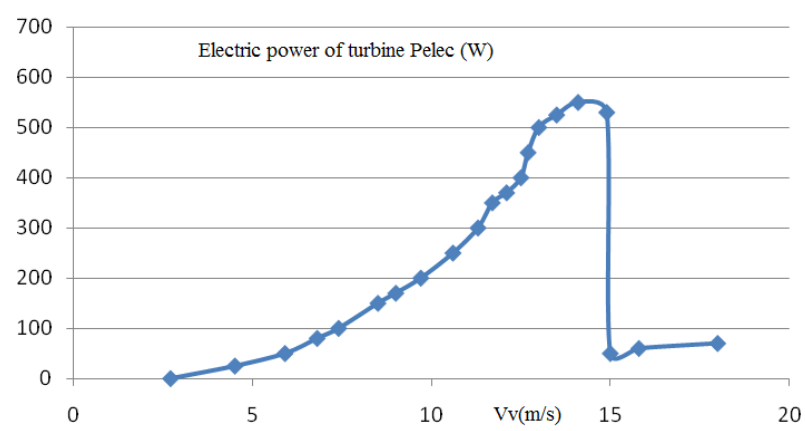

Fig. 12. Curve of electrical power of turbine

This value is obtained for a specific speed $\lambda=9$, it's represented by the Figure 13. Thus, to optimize power conversion, we must try to maintain this reduced speed by varying the mechanic speed $\Omega$ of turbine when the speed of wind Vv varies (Figure 14).

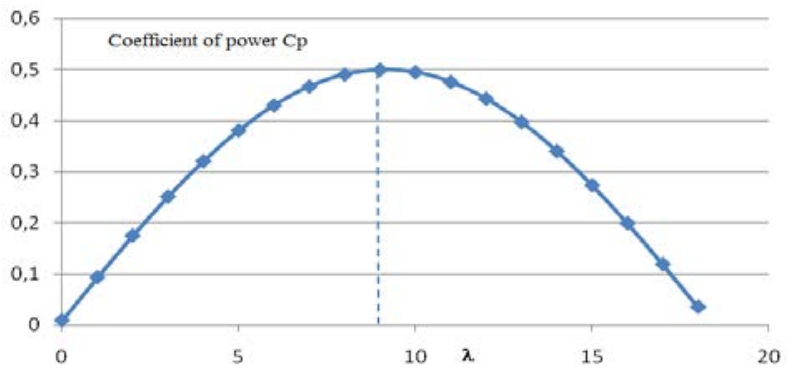

Fig. 13. Coefficient $\mathrm{Cp}$ for $\mathrm{Vv}=12 \mathrm{~m} / \mathrm{s}$

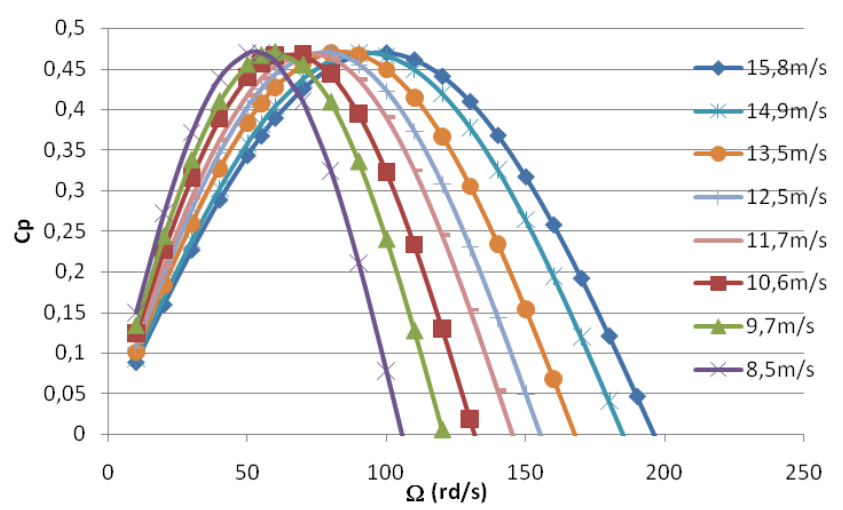

Fig. 14. Coefficient $C_{p}$ for various $\mathrm{Vv}$

More, the measurements make possible to validate the adopted control and to test the reliability and the technical performances of the installation. A typical implementation of our control, illustrated by the Figure 15 - a, allows meteorological data in real time every $15 \mathrm{~min}$ through a lighting sensor LDR and temperature sensors LM35 (Figure 15 - b). These two sensors are connected to the ADC (Analog digital converter) of Arduino. The optimal frequency is transmitted to the inverter through PWM (Pulse width modulation). The process flowchart of the implemented algorithm is given by figure 15-c. 


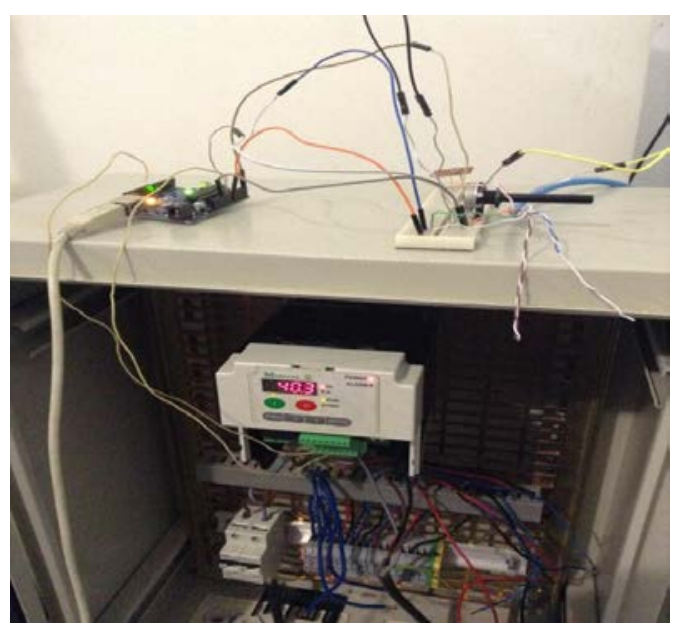

(a)

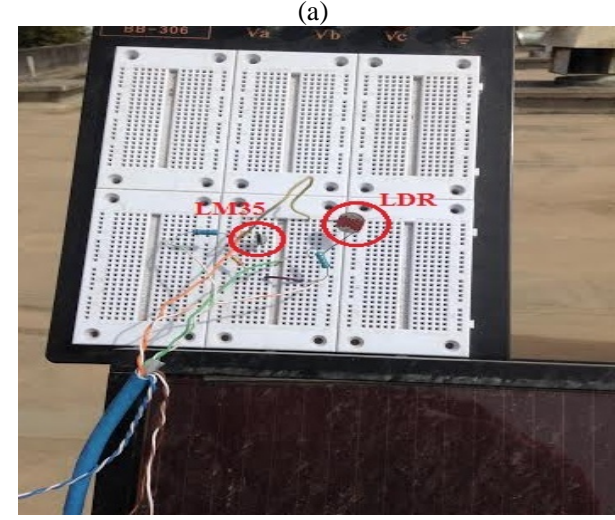

(b)

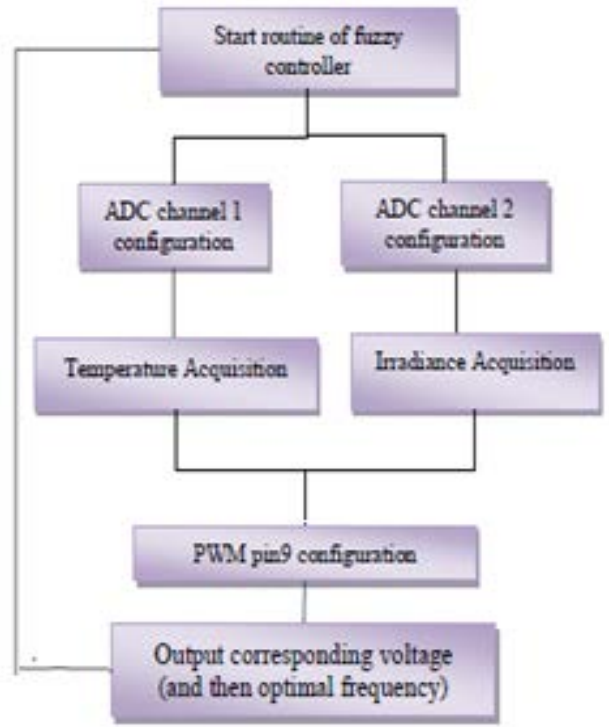

(c)

Fig. 15. (a) Inverter and implementation of optimum frequency (b) Data acquisition (c) Process flowchart of the implemented algorithm

for annual measures of the conditions climatic (EC, Ta, Tp and $\mathrm{Vv}$ ) in four typical months (Figures 16 - a, Figure 16 - b, Figure 16 - c, Figure 16 - d), we measure the corresponding stator frequency fS which follows an increasing function with insulation EC and the junction temperature Tp (Figure 17), this frequency is applied to the inverter requiring the PV voltage corresponding to the maximum power point and it's decreasing as a function of ambient temperature (Figure 18).

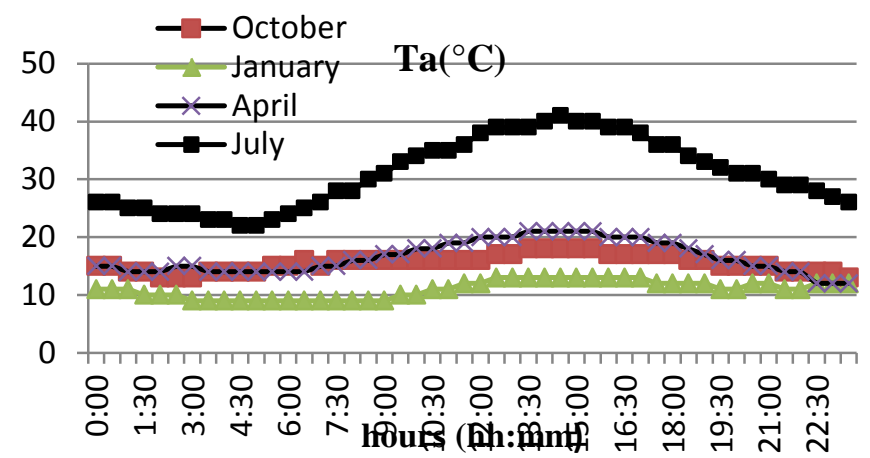

(a)

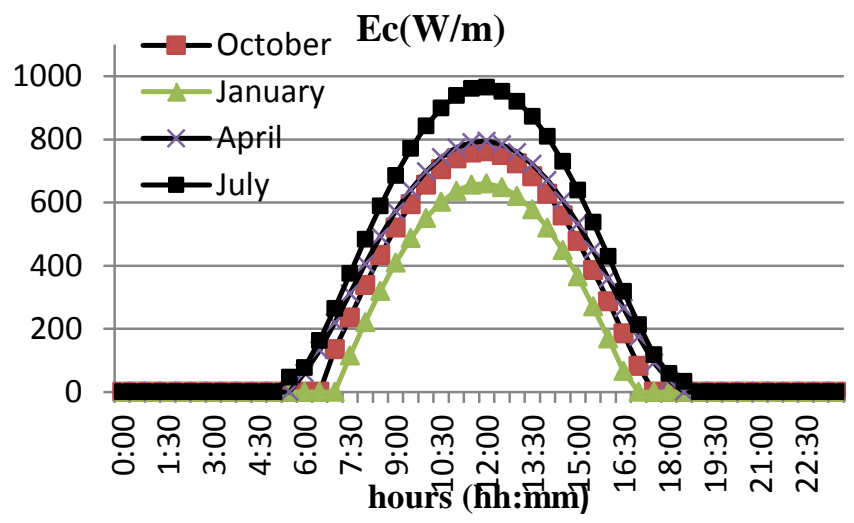

(b)

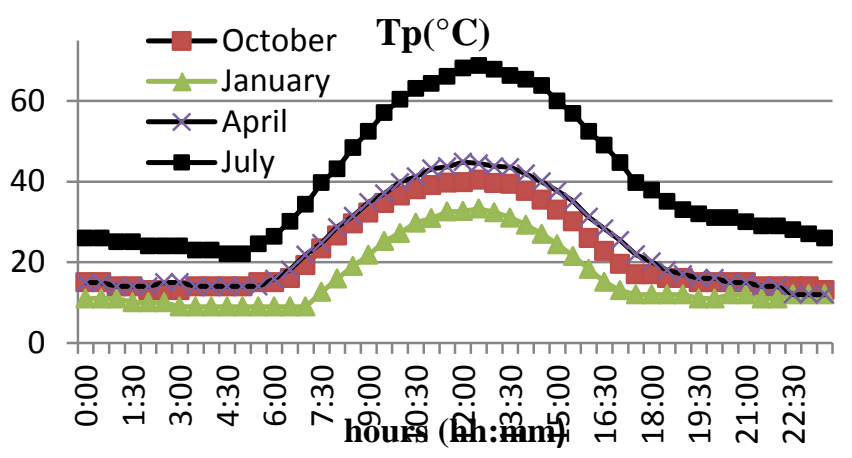

(c)

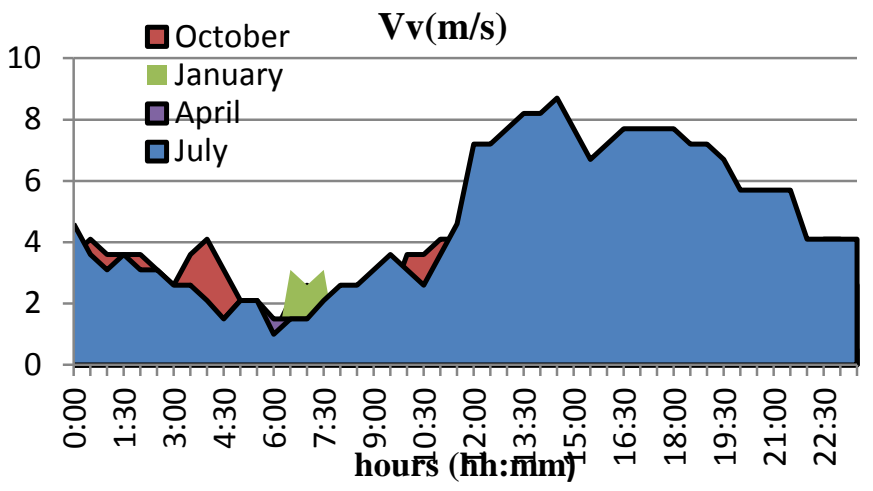

(d)

Fig. 16. (a) Average ambient temperature (b) Average ambient insulation (c) Average junction temperature (d) Average wind speed 
fs(Hz)

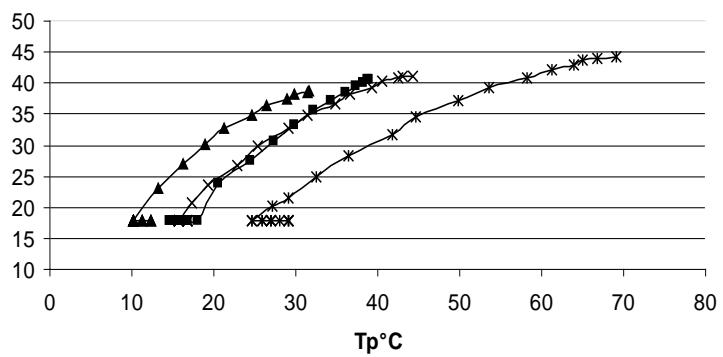

Fig. 17. Frequency according junction temperature

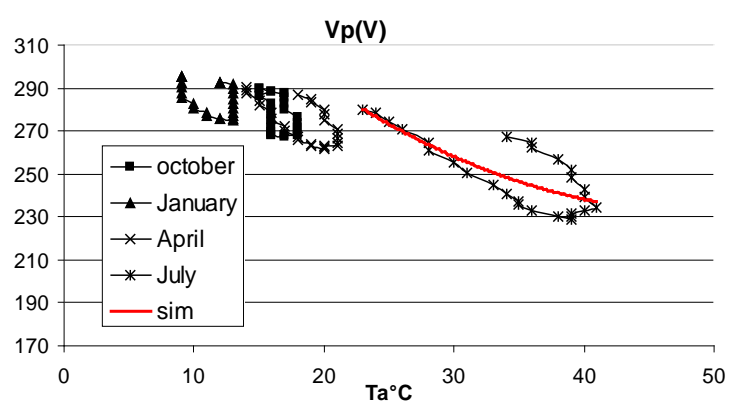

Fig. 18. PV tension according ambient temperature

With this control, we show that the flow Q obeys the first law of similarity in function of the illumination that is the junction temperature and we find that the average water pumped from our system is the order of $18 \mathrm{~m} 3$ / day to an overcast sky (Figure 19).

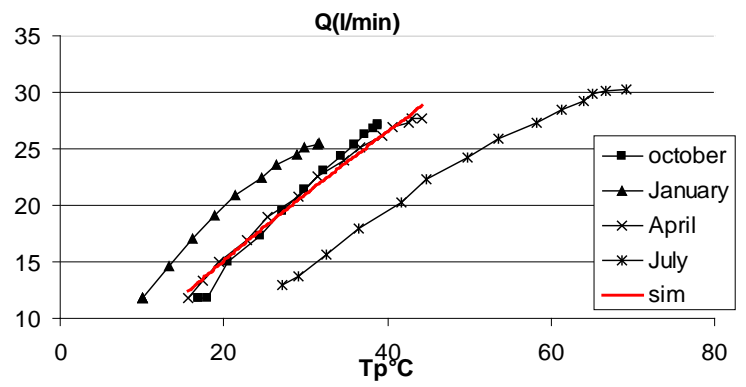

Fig. 19. Flow according junction temperature

This command allows maintaining optimal voltage operation of the pumping system; this voltage is around $240 \mathrm{~V}$ for strong winds and high temperatures and around $260 \mathrm{~V}$ for low winds and intense irradiance. This voltage Vp depends essentially of the temperature variation. So, we can conclude that our established control ensures optimal transfer between the sources and the water pumped.

In addition to, these measurements are agreements with the digital simulations, for example, we illustrate the characteristic $\mathrm{H}_{\mathrm{m}}(\mathrm{Q})$ at constant speed of the and check a good reliability of the operation of the structure (Figure 20). In addition, the applied value of frequency fs makes to function the multisources in its optimum point ensuring an optimum efficiency of the structure (Figure 21 and Figure 22).
Yearly Head of pump (m)

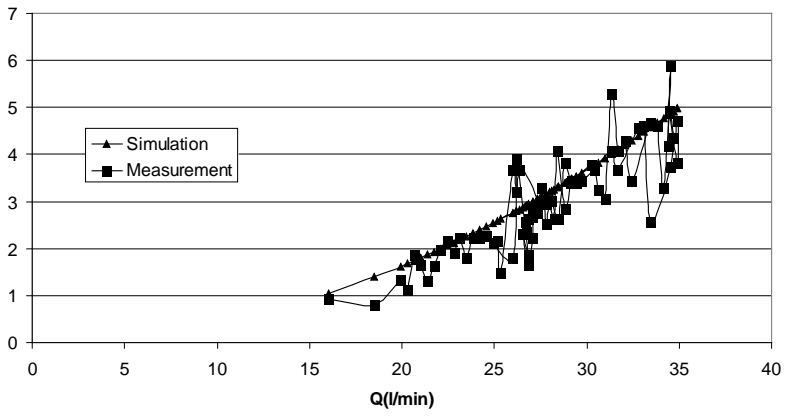

Fig. 20. Yearly Head of pump according flow

Yearly efficiency of pump (\%)

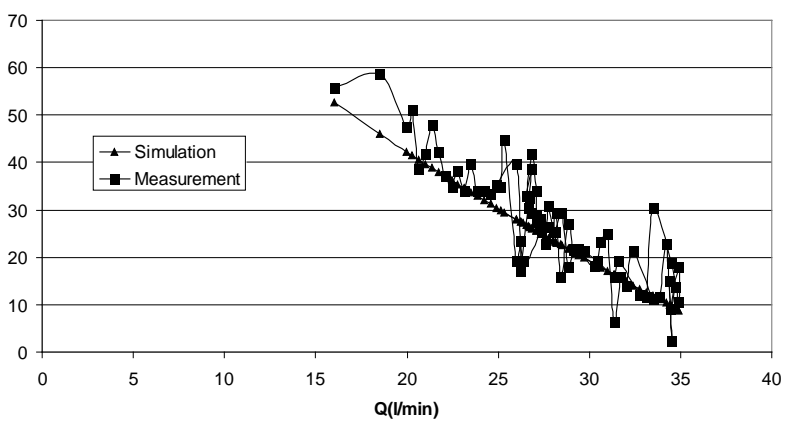

Fig. 21. Yearly efficiency of pump according flow

Yearly efficiency of PV installation (\%)

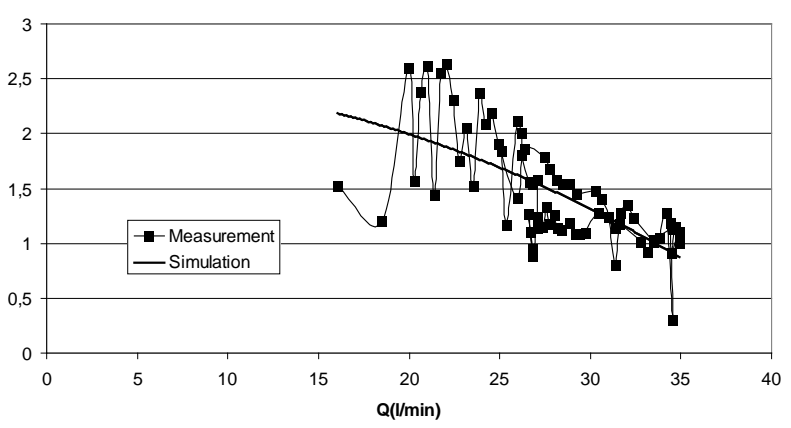

Fig. 22. Yearly efficiency of PV system according flow

\section{CONCLUSION}

We presented an atypical bond graph model of a pumping hybrid installation, then we established a optimum V/f control in function of the climatic conditions, finally, some measurements were carried out on the experimental device, they allowed us to validate the adopted control and to check the studied operation reliability of hybrid chains. These tests show that we can control the pumping system with a certain value of wind speed, low illumination and medium temperatures. As future work, we intend to apply diagnostic tools directly on bond graph for the supervision of the system; moreover we intend to apply robust controls as fuzzy logic and sliding mode on a desalination system and an agricultural greenhouse with embedded targets Namely STM32 and FPGA board. 


\section{REFERENCES}

[1] Bianchini A, Magnelli N, Ferrara G, Carnevale E.A, Ferrari L. Optimization of a PV-wind-Diesel Hybrid System for a Remote Standalone Application. Energy Proc 2015; 81: 133 - 145.

[2] Maleki A, Pourfayaz F. Optimization of grid independent diesel-based hybrid system for power generation using improved particle swarm optimization algorithm. Int J of Smart Elec Enginee 2015; 4: 29-36.

[3] Cherif H, Belhadj J. Energy output estimation of hybrid WindPhotovoltaic power system using statistical distributions. J of Elec Sys 2014; 10: 117-132.

[4] Brian D.V, Byron A.N. Analysis of off-grid hybrid wind turbine/solar PV water pumping systems. Sol Energy 2012; 86: 1197-1207.

[5] Roberto Valer L, Melendez T.A, Cristina Fedrizzi M, Zilles R. Variablespeed drives in photovoltaic pumping systems for irrigation in Brazil, Sus Energy Tech and Assess 2016; 15: 20-26.

[6] Zeddini M.A, Pusca R, Sakly A, Mimouni M.F. PSO-based MPPT control of wind-driven Self-Excited Induction Generator for pumping system, Renew Energy 2016; 95: 162-177.

[7] Paynter H.M. Analysis and Design of Engineering Systems. M.I.T. Press Cambridge 1961.

[8] Roboam X, Gandanegara G. Causal Bond Graph of Unbalanced Multiphase Electrical Systems. In: International Conference on Integrated Modeling \& Analysis in Applied Control \& Automation, Genoa, Italy, 2004; 28-30.

[9] Dauphin-Tanguy G, Les Bond Graphs, Hermès edition, Paris: 2000.

[10] Karnopp D.C, Margolis D.L, Rosenberg R.C. System Dynamics: Mod Simu, and Con of Mecha Sys. John Wiley \& Sons, New York 2012.

[11] Trajković D.M, Nikolić V.D, Antić D.S, Nikolić S.S, Perić S.Lj. Application of the hybrid bond graphs and orthogonal rational filters in sag voltage effect reduction. Electro and Elec Enginee 2013;19: 25-30.

[12] Madansure V, Banerjee S, Mukherjee A, Chattopadhyay P. Modelling and Simulation of PV-Powered Intermittent Load Systems by Bond Graph Technique. Sol Energy 1991; 55: 367-375.

[13] Roboam X, Astier S, Foch H, Fontès G, Gandanegara G, Piquet H, Saisset R, Sareni B, Turpin C. Graphes de liens causaux pour systèmes à énergie renouvelable (partie 2). Techniques de l'ingénieur, 2007.

[14] Mukerjee A, Karmakar R, Samantaray AK. Modeling of basic induction motors and source loading in rotor-motor systems with regenerative force field. Sim Prac and Theo 1999; 7: 563-576.

[15] Karnopp D. State Functions and Bond Graph Dynamic Models for Rotary, Multu_winding Electrical Machines. J of the Frank Insti 1991; 328: 45-54.

[16] Junco S. Real-and Complex-Power Bond Graph Modeling of the Induction Motor. International conference on bond graph modeling and simulation, San Francisco, USA 1999; 17-20.

[17] Sanchez R, Colas F, Dauphin-Tanguy G, Guillaud X. Coupling of classical and renewable energy sources. International Conference on Bond Graph Modelling, Orlando Florida, USA 2010.

[18] Sahm D. A Two-Axis, Bond Graph Model of the Dynamics of Synchronous Electrical Machines. J of the Frank Inst 1979; 3: 205-218.
[19] Batlle C, Cerezo AD. Bond graph models of electromechanical systems, The AC generator case. IEEE Int Sympo on Ind Electro, Cambridge, UK 2008; 1064 - 1069.

[20] Achir A, Sueur S, Dauphin-Tanguy G. Bond Graphs and Flatness Based Control of a Salient Permanent Magnetic Synchronous Motor. J of Sys and Cont Engin 2005; 219: 461-476.

[21] Azmani A, Dauphin-Tanguy G. Program for computer aided modelling and analysis. In: Bond graph for Engineers. Elsevier Science Pub, 1992; 263-278.

[22] Jean Thoma, B Ould Bouamama, Modelling and simulation in thermal and chemical engineering: A bond graph approach. Book, Springer Science \& Business Media, 2013

[23] Karnopp D.C, Margolis D.L, and Rosenberg R.C, System Dynamics, Mod and Sim of Mecha Sys. John Wiley \& Sons Inc., Fourth edition, 2005.

[24] Sanchez R, Dauphin-Tanguy G, Guillaud X, Colas F. Bond Graph Based Control of a Three Phase Inverter with LC Filter Connection to Passive and Active Loads. Sim Mod Prac and Theo 2010; 18: 1185-1198.

[25] Umesh B, Umanand L. Bond graph model of doubly fed three phase induction motor using the Axis Rotator element for frame transformation. Sim Mod Prac and Theo 2008; 16: 1704-1712.

[26] Mezghani D, Cabani I, Ellouze M, Mami A. Linearizing control of a photovoltaic structure and stability by lyapunov directly on bond graph. J of Elec Sys, 2007; 4: 181-192.

[27] Olorunfemi O. Analysis of current source induction motor drive fed from photovoltaic energy source. IEEE T on Energy Conv 1991; 6: 99106.

[28] Ahmad GE, Hussein HMS, El-Ghetan HH. Theoretical Analysis and Experimental Verification of PV modules. Renew Energy 2003; 28: 1195-1168.

[29] Nichita C, Luca D. Large Band Simulation of the Wind Speed for Real Time Wind Turbine Simulator. IEEE T Energy 2002; 17: 523-529.

[30] Bratcu A.I, Munteanu I, Bacha S, Picault D, Raison B. Cascaded DCDC converter photovoltaic systems: power optimization. IEEE T Ind. Electron. 2011; 58: 403-411.

[31] Saied M, Hanafy A, Elgabaly MA, Sharaf A. Optimal design parameters for a PV array coupled to a dc motor via dc-dc transformer. IEEE T on Energy Conver, 1991; 6: 258-264.

[32] Dongbing Z, Designing a SEPIC converter, National Semiconductor (Texas Instrument), Application Note 2013.

[33] Hmidet A, Hasnaoui Z, Dhifaoui R. Digital control of MPPT structures for water pumping systems. International Conference on Power Electronics, Machines and Drives, Manchester, UK 2014.

[34] Mezghanni D, Andoulsi R, Mami A, Dauphin-Tanguy G. Bond graph modeling of a photovoltaic system feeding an induction motor-pump. Sim Mod Prac and Theo 2007; 15: 1224-1238.

[35] Broenink. J.F, 20-sim software for hierarchical bond-graph/blockdiagram models, Sim Mod Prac and Theo 1999; 7: 481-492.

[36] Susmethaa Siri R, Keerthana C, Arthi A, Senthil Rani S. Hybrid Water Pumping Control System for Irrigation using Arduino. Int J of Enginee Res \& Techno, 2015; 4: 859-863. 